\title{
Managing Stubborn Oomycete Plant Pathogens
}

\author{
Chandrasekar S. Kousik, ${ }^{1,+}$ Lina M. Quesada-Ocampo, ${ }^{2}$ Anthony Keinath, ${ }^{3}$ Mary Hausbeck, ${ }^{4}$ Leah Granke, ${ }^{5}$ Rachel Naegele, ${ }^{6}$ and \\ Pingsheng $\mathrm{Ji}^{7}$ \\ ${ }^{1}$ USDA, Agricultural Research Service, U.S. Vegetable Laboratory, Charleston, SC 29414 \\ ${ }^{2}$ Department of Entomology and Plant Pathology, North Carolina State University, Raleigh, NC 27695-7613 \\ ${ }^{3}$ Clemson University, Coastal Research and Education Center, Charleston, SC 29414 \\ ${ }^{4}$ Department of Plant, Soil, and Microbial Sciences, Michigan State University, East Lansing, MI 48824 \\ ${ }^{5}$ Corteva Agriscience, Indianapolis, IN 46268 \\ ${ }^{6}$ USDA, Agricultural Research Service, Sugar Beet and Bean Research Unit, East Lansing, MI 48824 \\ ${ }^{7}$ Department of Plant Pathology, University of Georgia, Tifton, GA 31794 (deceased)
}

Accepted for publication 26 August 2021.

\section{Abstract}

Diseases caused by oomycete plant pathogens result in devastating losses to agriculture and native forests, despite the significant research efforts that have advanced our understanding of these organisms. Limiting these pathogens has been challenging to plant pathologists and plant health practitioners. In this first focus issue, titled Managing Stubborn Oomycete Plant Pathogens, Plant Health Progress has assembled an array of manuscripts on the biology and management of Phytophthora, Pythium, Pseudoperonospora, Peronospora, and Aphanomyces spp. This focus issue has 28 peer-reviewed papers including three diagnostic guides, three mini-reviews, three briefs, two surveys, and 17 research papers. Of the 28 papers, 20 are on diseases caused by Phytophthora, four on Pythium, three on downy mildews, and one on Aphanomyces. All advance our understanding of these stubborn oomycete pathogens.
More than 1,200 oomycete species are known and named, and over half of these are obligate downy mildews (Thines 2018). Of the facultative biotrophic oomycetes, the well-known Phytophthora species have devastated agricultural and horticultural crops since well before Anton de Bary first described Phytophthora. Many other oomycetes cause downy mildews, white rusts, damping-off, and other diseases of significant economic impact worldwide. Given the recent advances in the development of new fungicides, diagnostic tools, population biology, host resistance, and integrated management strategies, Plant Health Progress (PHP) selected Managing Stubborn Oomycete Plant Pathogens for its first focus issue. This focus issue is dedicated to the memory of guest editor Pingsheng Ji, who passed away unexpectedly while the issue was in production.

We received a tremendous response to the call for papers seeking to spotlight diseases caused by these difficult-to-manage plant pathogens. This focus issue addresses original biological and practical questions that advance our conceptual knowledge of management strategies of oomycetes. It is composed of 28

\section{Corresponding author: C. S. Kousik; shaker.kousik@usda.gov}

Disclaimer: Mention of a proprietary product does not constitute an endorsement or recommendation by the USDA-ARS for its use, nor does it imply exclusion of other products that may be suitable.

The author(s) declare no conflict of interest.

This article is in the public domain and not copyrightable. It may be freely reprinted with customary crediting of the source. The American Phytopathological Society, 2021. peer-reviewed papers, including three diagnostic guides, three mini-reviews, 17 research papers, two surveys, and three $P H P$ briefs. The majority $(71 \%)$ of the manuscripts address diseases caused by Phytophthora on agronomic, horticultural, and nursery crops. Of these articles, five focus on Phytophthora capsici, five on Phytophthora species infecting nursery crops, three on $P$. sojae, two on $P$. infestans, two on $P$. pini on walnuts, and three on various other Phytophthora species. Of the remaining eight papers, four are on Pythium, two are on Peronospora, one on Pseudoperonospora, and a diagnostic guide on Aphanomyces.

Diagnostic guides published in $P H P$ are a great resource for plant disease diagnosticians, extension agents, and plant health practitioners, enabling rapid diagnosis of varied plant samples received at clinics and when advising growers. This focus issue includes three diagnostic guides on oomycetes. Parada-Rojas et al. (2021) describe the wide host range of P. capsici and keys to diagnosing the varied symptoms it induces on the three major vegetable host families: Solanaceae, Cucurbitaceae, and Fabaceae. Similarly, all major commercially cultivated cucurbit crops are susceptible to Pythium damping-off and root and stem rot. The diagnostic guide by Toporek and Keinath (2021) describes the symptoms and summarizes the techniques for isolation, identification, and conducting pathogenicity tests for the major Pythium species infecting cucurbits. The diagnostic guide by Zitnick-Anderson et al. (2021) thoroughly reviews the techniques for handling an oomycete pathogen found throughout the midwestern and northwestern United States, Aphanomyces euteiches, which causes Aphanomyces root rot on peas, alfalfa, and lentils.

Three review articles are highlighted in this $P H P$ focus issue. The review by Bickel and Koehler (2021) on damping-off of corn 
consolidates the species of Pythium reported as corn pathogens and provides insights into the management strategies. The article further discusses variations in fungicide sensitivity observed in Pythium species infecting corn. Phytophthora root rot is a severe problem in the nursery industry, and the presence of diverse Phytophthora communities makes it less likely that a single disease management strategy will be broadly effective (Weiland 2021). The review by Weiland (2021) also suggests that a combination of approaches that considers the individual weakness of each Phytophthora species present in a particular location will most likely be needed to manage root rot for the long term in nursery industries. Basil downy mildew caused by Peronospora belbahari results in severe yield losses in field- and greenhouse-grown basil across the world. Patel et al. (2021) summarize effective strategies for managing basil downy mildew, using resistant varieties, environmental modifications, and appropriate fungicide applications.

$P$. capsici is a well-known destructive oomycete pathogen of many important vegetable crops, particularly peppers and various squashes. Dura et al. (2021) suggest the use of relatively less susceptible jalapeno cultivars in infested fields for managing Phytophthora blight. Lujan et al. (2021) describe phenolics extracted from pecan byproducts as an additional option for managing Phytophthora blight of peppers. Kousik et al. (2021) describe new sources of resistance to Phytophthora crown and root rot in squashes. They also describe the relationship of the new sources of resistance to cultivated squashes and how these can be utilized for developing Phytophthora crown and root rot resistant rootstocks for watermelon grafting and resistant squash varieties for human consumption. Hudson et al. (2021) suggest that testing irrigation pond water in Georgia for $P$. capsici can help prevent severe disease outbreaks on vegetable crops. They describe the development of a novel filtration method in conjunction with a LAMP assay to survey for the presence of $P$. capsici in pond water.

Many other Phytophthora species can also be dispersed across fields via water. Browne et al. (2021) describe that flooding rivers in California resulted in infections of walnut trees by various Phytophthora species and that $P$. pini, $P$. chlamydospora, and $P$. gonapodyides were readily isolated from bleeding cankers on walnut scions. Browne et al. (2021) further suggest that chemical and/or genetic strategies to protect walnut orchards that are prone to flooding will be valuable to growers. To develop genetic resources, Zaini et al. (2021) describe a rapid in vitro phenotypic assay to prescreen walnut genotypes for resistance to $P$. pini. It is well-known that stress caused by flooding and waterlogging predisposes crops to infection by plant pathogens, especially oomycetes. In the study by Dron et al. (2021), phenotyping for tolerance to waterlogging was used as a proxy for $P$. medicaginis resistance in chickpea. The authors further suggest that phenotyping chickpeas for root depth and the lack of adventitious root development under waterlogged conditions may be useful for identifying Phytophthora root rot resistance traits during the early stage of breeding for disease resistance.

Phytophthora root and stem rot of soybean caused by $P$. sojae is an important disease that causes significant yield losses across the United States and Canada (as per recent data; Bradley et al. 2021). Management of $P$. sojae relies primarily on growing resistant soybean cultivars. Based on studies with $326 P$. sojae isolates and 15 soybean differentials, Matthiesen et al. (2021a) identified the presence of 15 pathotypes in Iowa and 10 in Nebraska. In another study, Matthiesen et al. (2021b) compared two baiting techniques - a leaf disc and a seedling method-to recover $P$. sojae from soil to characterize pathotypes prevailing in soybean fields. The leaf disc method enabled recovery of more $P$. sojae isolates, which could in turn help breeders and agronomists deploy soybean cultivars with the appropriate resistance (Rps) genes. Similar to the above studies, Chowdhury et al. (2021) describe the presence of 48 unique pathotypes of $P$. sojae from soybean fields in South Dakota.

Potato late blight caused by $P$. infestans, which led to the great Irish potato famine in the mid-19th century, has been well studied and described by many researchers (Mabon et al. 2021; Thines 2018). Mabon et al. (2021) describe the development of an improved PCR method for the quick identification of mating types of $P$. infestans without conventional paring on Petri plates between known tester and unknown isolates. Their multiplex PCR results were validated by testing 1,441 samples and can be utilized on both live and stored materials, including on FTA cards, thus adding another tool for population typing (Mabon et al. 2021). Larson et al. (2021), who worked with P. infestans isolates from Wisconsin, write that the isolates of US-23, which belongs to the A1 mating type, were significantly more sensitive to mefenoxam than the US-8 isolates (A2 mating type). They further suggest that continued screening for sensitivity to mefenoxam can help identify the mechanism of tolerance and aid in the development of best management practices.

Challenges posed by Phytophthora species to the nursery industry have been well documented. In the current $P H P$ focus issue, Elliott et al. (2021b) describe the effectiveness of collaboration among multiple agencies in strengthening applied research, leading to the mitigation of $P$. ramorum at the Bloedel Reserve, a public botanical garden in Washington State. The combination of management measures adapted in the Bloedel Reserve to limit the spread of the pathogen included detection and removal of positive host plants, soil steaming, fungicide sprays, and specific signage. Similarly, to exclude Phytophthora from nursery planting stock used in habitat restoration projects, Swiecki et al. (2021) describe the development of an accreditation program to produce Phytophthora-free plants native to California. This program demonstrated that stock plants free of Phytophthora can be reliably produced by complying with an integrated program of clean nursery production practices, which included a sensitive leachate baiting technique to detect the pathogen. Beaulieu et al. (2021) researched 243 isolates of five Phytophthora species from nurseries and detected mefenoxam-insensitive isolates in three species. They recommend that this fungicide should no longer be used to manage oomycetes in Maryland nurseries. They further suggest that the use of fluoxastrobin should be limited owing to the prevalence of insensitive isolates of the various Phytophthora species. Alsultan et al. (2021) describe high levels of genetic diversity among P. palmivora isolates causing black pod of cocoa in Malaysia.

In their quest for additional chemical alternatives to manage $P$. cactorum and P. nicotianae on strawberry, Marin and Peres (2021) identified mandipropamid, fluopicolide, oxathiapiprolin, and cymoxanil as effective in managing crown rot and leather rot. They further suggest that adding these new chemicals to the toolbox will help manage development of resistance in these two Phytophthora species. Zhang et al. (2021) describe that ethaboxam and mefenoxam are effective in the management of Pythium root rot caused by $P$. myriotylum during tobacco transplant production in greenhouses. A research paper on downy mildew of cucurbits by Jones et al. (2021), using bioassays over multiple years in Delaware, Maryland, Pennsylvania, and New York to assess fungicide efficacy, points out that chlorothalonil, 
oxathiapiprolin, and a combination of zoxamide + chlorothalonil (trade name: Zing!) were very effective in suppressing Pseudoperonospora cubensis. In addition, they report that cyazofamid and propamocarb hydrochloride were also effective.

Oomycete plant pathogens infecting new hosts, extending their range across the country, or becoming insensitive to pesticides are regularly reported in PHP briefs. Three new hosts for P. ramorum, salal, Oregon grape, and red huckleberry, common shrubs in northwestern forests, were identified in Washington (Elliott et al. 2021a). Parikh et al. (2021) described the ability of Pythium sylvaticum to infect chickpea, lentil, and pea crops in Montana and determined that the pathogen was insensitive to metalaxyl and ethaboxam. Purayannur et al. (2021) report on downy mildew caused by Peronospora chenopodii-ambrosioidis in North Carolina on epazote, an herb commonly used in Mexican cuisine.

In conclusion, this focus issue brings together 28 papers dealing with various aspects of managing oomycete plant pathogens, including host resistance, chemical alternatives, monitoring, regulatory response, best management practices, and other techniques. However, it is also evident from several papers that more research is needed to make some of these strategies easy to adopt by growers who deal with these pathogens on a day-to-day basis.

\section{Acknowledgments}

We express our sincere gratitude to all the authors for their valuable contributions to this focus issue and for the overwhelming response to the call for papers. Bringing together a focus issue with peerreviewed papers would not have been possible without the support and valuable time of many anonymous reviewers, who responded by reviewing the manuscripts in a timely manner. We also express our sincere thanks to the PHP production team at APS for their hard work and professionalism.

\section{Literature Cited}

Alsultan, W., Vadamali, G., Saud, H. M., Khairulmazmi, A., Wong, M. Y., Jaaffarand, A. K. M., Al-Sadi, A. M., Rashed, O., and Nasehi, A. 2021. Phylogenetic analysis and genetic diversity of Phytophthora palmivora causing black pod disease of cocoa in Malaysia. Plant Health Prog. 22: 260-271

Beaulieu, J., Munera, J. D., and Balci, Y. 2021. Detection of oomycideinsensitive Phytophthora isolates in Maryland ornamental nurseries and Mid-Atlantic landscapes provide data for reconsidering management strategies. Plant Health Prog. 22:281-286.

Bickel, J. T., and Koehler, A. 2021. Review of Pythium species causing damping-off in corn. Plant Health Prog. 22:219-225.

Bradley, C. A., Allen, T., Sisson, A. J., Bergstrom, G. C., Bissonnette, K. M., Bond, J. P., Byamukama, E., Chilvers, M. I., Collins, A., Damicone, J., Dorrance, A. E., Dufault, N., Esker, P., Faske, T., Fiorellino, N., Giesler, L., Hartman, G., Hollier, C., Isakeit, T., Jackson, T. A., Jardine, D., Kelly, H. M., Kemerait, R. C., Kleczewski, N., Koehler, A., Kratochvil, R., Kurle, J., Malvick, D., Markell, S., Mathew, F., Mehl, H., Mehl, K., Mueller, D. S., Mueller, J. D., Nelson, B. D., Overstreet, C., Padgett, B., Price, P. P., III, Sikora, E., Small, I., Smith, D. L., Spurlock, T., Tande, C., Telenko, D. E. P., Tenuta, A., Thiessen, L. D., Warner, F., Wiebold, B., and Wise, K. 2021. Soybean yield loss estimates due to diseases in the United States and Ontario, Canada, from 2015 to 2019. Plant Health Prog. https://doi.org/10.1094/PHP-01-21-0013-RS.

Browne, G. T., Hasey, J. K., Ott, N. J., Forbes, H., Arnold, K., and Milliron, L. 2021. Flooding by California rivers results in walnut scion infections by species of Phytophthora. Plant Health Prog. 22:368-373.

Chowdhury, R. N., Tande, C., and Byamukama, E. 2021. Common Phytophthora sojae pathotypes occurring in South Dakota. Plant Health Prog. 22:374-379.

Dron, N., Sutton, T., Harden, S., Simpfendorfer, S., and Hobson, K. 2021. Phenotyping for waterlogging tolerance as a proxy for Phytophthora medicaginis resistance in chickpea. Plant Health Prog. 22:287-293.

Dura, S., Lujan, P. A., Guzman, I., Steiner, R., and Sanogo, S. 2021. A field evaluation of jalapeño and non-jalapeño chile pepper resistance to
Phytophthora blight caused by Phytophthora capsici. Plant Health Prog. 22:309-315.

Elliott, M., Rollins, L., Bourret, T., Hulbert, J. M., and Chastagner, G. 2021a. Three new hosts for Phytophthora ramorum confirmed in Washington State: Salal, Oregon grape, and red huckleberry. Plant Health Prog. 22:389-391.

Elliott, M., Strenge, D., Hulbert, J. M., and Chastagner, G. A. 2021 b. Multiagency collaboration strengthens applied research and mitigation of Phytophthora ramorum at a botanical garden in Washington State. Plant Health Prog. 22:240-249.

Hudson, O., Waliullah, S., Ji, P., Hand, J., Price, J., Hancock, G., Carlson, S., Kichler, J., Price, T., Dowdy, M., Hayes, B., and Ali, E. 2021. Detection of Phytophthora capsici from irrigation ponds in South Georgia. Plant Health Prog. 22:380-383.

Jones, J. G., Everts, K. L., McGrath, M. T., and Gugino, B. K. 2021. Efficacy of fungicides for Pseudoperonospora cubensis determined using bioassays over multiple years in the Mid-Atlantic and Northeastern United States. Plant Health Prog. 22:355-361.

Kousik, C. S., Vogel, G., Ikerd, J. L., Mandal, M. K., Mazourek, M., Smart, C. D., and Turechek, W. W. 2021. New sources of resistance in winter squash (Cucurbita moschata) to Phytophthora crown rot and their relationship to cultivated squash. Plant Health Prog. 22:323-331.

Larson, E. R., Migliano, L. E., Chen, Y., and Gevens, A. J. 2021. Mefenoxam sensitivity in US-8 and US-23 Phytophthora infestans from Wisconsin. Plant Health Prog. 22:272-280.

Lujan, P., Dura, S., Guzman, I., Grace, M., Lila, M. A., Steiner, R., and Sanogo, S. 2021. Efficacy of pecan husk and shell phenolic extracts against Phytophthora blight in chile pepper. Plant Health Prog. 22: 342-347.

Mabon, R., Guibert, M., Corbière, R., and Andrivon, D. 2021. An improved PCR method for rapid and accurate identification of mating types in the late blight pathogen Phytophthora infestans. Plant Health Prog. 22:362-367.

Marin, M. V., and Peres, N. A. 2021. Improving the toolbox to manage Phytophthora diseases of strawberry: Searching for chemical alternatives. Plant Health Prog. 22:294-299.

Matthiesen, R. L., Schmidt, C., Garnica, V. C., Giesler, L. J., and Robertson, A. E. 2021a. Comparison of Phytophthora sojae populations in Iowa and Nebraska to identify effective Rps genes for Phytophthora stem and root rot management. Plant Health Prog. 22:300-308.

Matthiesen, R. L., Schmidt, C., and Robertson, A. E. 2021b. Comparison of baiting techniques for recovering Phytophthora sojae from soybean fields in Iowa. Plant Health Prog. 22:316-322.

Parada-Rojas, C. H., Granke, L., Naegele, R. P., Hansen, Z., Hausbeck, M. K., Kousik, C. S., McGrath, M. T., Smart, C. D., and QuesadaOcampo, L. M. 2021. A diagnostic guide for Phytophthora capsici infecting vegetable crops. Plant Health Prog. 22:404-414.

Parikh, L. P., Moparthi, S., Crutcher, F. K., and Burrows, M. E. 2021. Identification of metalaxyl- and ethaboxam-insensitive Pythium sylvaticum pathogenic to pulse crops in Montana, U.S.A. Plant Health Prog. 22:387-388.

Patel, J. S., Wyenandt, C. A., and McGrath, M. T. 2021. Effective downy mildew management in basil using resistant varieties, environment modifications, and fungicides. Plant Health Prog. 22:226-234.

Purayannur, S., Munster, M. J., Bertone, M. A., and Quesada-Ocampo, L. M. 2021. First report of downy mildew caused by Peronospora chenopodiiambrosioidis on epazote (Dysphania ambrosioides) in North Carolina. Plant Health Prog. 22:384-386.

Swiecki, T. J., Bernhardt, E. A., Frankel, S. J., Benner, D., and Hillman, J. 2021. An accreditation program to produce native plant nursery stock free of Phytophthora for use in habitat restoration. Plant Health Prog. 22:348-354.

Thines, M. 2018. Oomycetes. Curr. Biol. 28:R812-R813.

Toporek, S. M., and Keinath, A. P. 2021. A diagnostic guide for Pythium damping-off and root and stem rot of cucurbits. Plant Health Prog. 22: 415-418.

Weiland, J. E. 2021. The challenges of managing Phytophthora root rot in the nursery industry. Plant Health Prog. 22:332-341.

Zaini, P. A., Lee, S. H., Leslie, C. A., Walawage, S. L., Jiang, C.-Z., Browne, G. T., Dandekar, A. M., and Kasuga, T. 2021. A rapid in vitro phenotypic assay of walnut shoots for prescreening resistance to Phytophthora pini. Plant Health Prog. 22:235-239.

Zhang, X., Johnson, C., and Reed, D. 2021. Management of Pythium myriotylum in tobacco transplant production greenhouses. Plant Health Prog. 22:250-259.

Zitnick-Anderson, K., Porter, L. D., Hanson, L. E., and Pasche, J. S. 2021. Identification, laboratory, greenhouse, and field handling of Aphanomyces euteiches on pea (Pisum sativum). Plant Health Prog. 22:392-403. 


\section{In Memoriam}

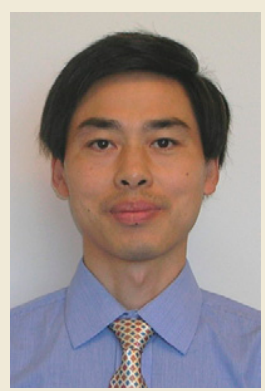

Pingsheng Ji

Pingsheng Ji, professor of plant pathology at the University of Georgia Tifton campus, passed away unexpectedly in May 202I at the age of 56. Dr. Ji had enthusiastically accepted the offer to serve as a guest editor for this focus issue because of his dedication to helping researchers and growers and his extensive experience in working with oomycetes, especially Phytophthora capsici. Prior to his passing away, he had completed all his editorial assignments.

Dr. Ji earned his master's degree from the Beijing Agricultural University in I988 and his doctorate in plant pathology from Auburn University, Alabama, in I999. He served as a vegetable pathologist with the University of Georgia from 2007 onward and focused his efforts on developing management strategies to help mitigate the impact of soilborne fungal and oomycete diseases. Dr. Ji contributed significantly to the areas of pathogen biology, ecology, and epidemiology, etiology, population genetics, and the integration of these approaches to help improve disease management strategies and reduce crop losses of major vegetables cultivated in Georgia. Dr. Ji extensively researched the biology, detection, and management of diseases caused by $P$. capsici, which is considered a major destructive pathogen on vegetable crops worldwide. He identified pepper and cucurbit germplasm with resistance to $P$. capsici and developed effective fungicide programs and cultural practices for managing Phytophthora diseases in watermelon, squash, and peppers. His research provided valuable information about the ecological and physiological nature of $P$. capsici and facilitated the development of resistant cultivars and effective management strategies.

He served as a co-organizer of the International Soilborne Oomycete Conferences held in 2013 and 2018 and pulled together the scientific program. He was also a member of the scientific committees of its predecessor, the International Phytophthora capsici Conferences, held once every 2 years from 2007 to 2013 and led the biology and epidemiology sessions. Dr. Ji was also an active member on several APS subject matter committees and served as the chair of the Integrated Plant Disease Management Committee. He served as an associate editor and senior editor for Plant Disease and as a panelist on several grant panels for USDA-NIFA and USDA-ARS.

Dr. Ji is survived by his wife, Hua Kang, and a daughter. PJ, as he was affectionately known to his friends and coworkers, was a kind person with an unassuming personality. His contributions have and will continue to significantly advance and impact the science of plant pathology. He will be greatly missed by the national and international members of the soilborne oomycete research community. 